\title{
Contribution of Streptokinase-Domains from Groups G and A (SK2a) Streptococci in Amidolytic /Proteolytic Activities and Fibrin-Dependent Plasminogen Activation: A Domain-Exchange Study
}

\author{
Maryam Rafipour ${ }^{1,2}$, Malihe Keramati ${ }^{3}$, Mohammad Mehdi \\ Aslani $^{2}$, Arash Arashkia $^{1}$ and Farzin Roohvand ${ }^{1 *}$ \\ ${ }^{1}$ Department of Virology, Pasteur Institute of Iran, Tehran, Iran; ${ }^{2}$ Department of Microbiology, Pasteur Institute \\ of Iran, Tehran, Iran; ${ }^{3}$ Department of Nanobiotechnology, Pasteur Institute of Iran, Tehran, Iran
}

Received 6 February 2019; accepted 16 March 2019; published online 28 August 2019

\begin{abstract}
Background: SK, a heterogeneous PA protein from groups A, C, and G streptococci (GAS, GCS, GGS, respectively)

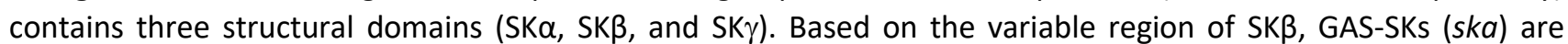
clustered as SK1 and SK2 (including SK2a/SK2b), which show low and high FG-dependent Plg activation properties, respectively. Despite being co-clustered as SK2a, GCS/GGS-SKs $(s k c g)$ variants display properties similar to SK1. Herein, by SK $\beta$ exchange between GGS (G88) and GAS-SK2a (STAB902) variants, the potential roles of SK domains in amidolytic/proteolytic activity and FG-bound-Plg activation are represented. Methods: Two parental $\mathrm{SK}_{\mathrm{G} 88}$ and $\mathrm{SK}_{\mathrm{STAB902}}$ genes were cloned into the $\mathrm{Ndel} / \mathrm{XhOl}$ site of pET26b expression vector. The two chimeric SK $\beta$-exchanged constructs ( $\mathrm{SK}_{\mathrm{C} 1}: \alpha_{\mathrm{G} 88}-\beta_{\mathrm{STAB}}-\gamma_{\mathrm{G} 88}$ and $\left.\mathrm{SK}_{\mathrm{C} 2} ; \alpha_{\mathrm{STAB}}-\beta_{\mathrm{G} 88^{-}} \mathrm{Y}_{\mathrm{STAB}}\right)$ were constructed by BstEll/BsiWl digestion/crossligation in parental plasmids. SKs were expressed in E. coli and purified by Ni-NTA chromatography. PA potencies of SKs were measured by colorimetric assay. Results: SDS-PAGE and Western-blot analyses confirmed the proper expression of $47-\mathrm{kDa}$ SKs. Analyses indicated that the catalytic efficiency $\left(\mathrm{K}_{\mathrm{cat}} / \mathrm{K}_{\mathrm{m}}\right)$ for amidolytic and proteolytic activity were less and moderately dependent on SK $\beta$, respectively. The increase of FG-bound-Plg activation for $\mathrm{SK}_{\mathrm{STABg02}} / \mathrm{SK}_{\mathrm{C} 1}$ containing SK2a $\beta$ was around six times, whereas for $\mathrm{SK}_{\mathrm{G}_{88}} / \mathrm{SK}_{\mathrm{C} 2}$ containing skcg $\beta$, it was four times. Conclusion: Although SK $\beta$ has noticeable contribution in FG-bound-Plg activation activity, it had minor contribution in fibrin-independent, amidolytic activity. These data might be of interest for engineering fibrinspecific versions of SK. DOI: 10.29252/ibj.24.1.15
\end{abstract}

Keywords: Plasminogen, Streptokinase, Thrombolytic therapy

Corresponding Author: Farzin Roohvand

Virology Department, Pasteur Institute of Iran, No. 69, Pasteur Ave., Tehran 1316943551, Iran; Tel./Fax: (+98-21) 66496682;

Mobile: (+98-912)4129269; E-mail: rfarzin@pasteur.ac.ir or farzin.roohvand2@gmail.com

\section{INTRODUCTION}

$\mathrm{C}$ onversion of inactive Plg into active protease plasmin in blood is the unique mechanism of all PAs such as TPA and SK that are used as fibrinolytic drugs for the treatment of life-threatening thrombotic disorders like infarction and stroke ${ }^{[1-3]}$. One of the limiting factors of fibrinolytic drugs is their specificity toward fibrin clots, which is important for the bleeding risk of the patients as a side effect of the treatment ${ }^{[4]}$. In this regard, PAs are categorized into two main groups, fibrin-specific and fibrin-

List of Abbreviations:

FG, fibrinogen; IPTG, isopropyl- $\beta$-D-thio-galactoside; Ni-NTA, nickel-nitriloacetic acid; PA, plasminogen activator; Plg, plasminogen; SK, streptokinase; SK2a, cluster2-streptokinase; SK $_{c}$, chimeric streptokinase; $\mathbf{t P A}$, tissue plasminogen activator 
independent agents ${ }^{[5]}$. Fibrin-specific PAs, like tPA, target fibrin-bound $\mathrm{Plg}$ and act specifically onto thrombus, whereas fibrin-independent ones such as SK have tendency toward circulatory $\mathrm{Plg}^{[4-6]}$. In fact, SK is not a proteolytic enzyme by itself, and its activity relies on several protein-protein interactions. At first, it binds to Plg and forms a binary 1:1 complex (activator complex) inducing conformational changes in the molecule that results in the generation of an amidolytically activated SK-Plg* complex capable of converting free Plg as the substrate to plasmin (pathway I, conformational activation pathway that is fibrin-independent). Finally, the Plg within the activator complex is converted to plasmin. SK can also bind to plasmin directly with higher affinity, compared with Plg, to form the SK-plasmin complex, which then it converts other Plg substrates to plasmin (pathway II, direct proteolytic activation pathway) ${ }^{[7,8]}$.

$\mathrm{SK}$ is secreted by $\beta$-hemolytic Streptococci of the Lancefield groups A (GAS), C (GCS), and G (GGS). $\mathrm{SK}$, as a virulence factor in the streptococcal pathogenesis (especially for GAS) isolated from a moderately virulent GCS (ATCC H46A), was traditionally used as a fibrinolytic drug for decades ${ }^{[9,10]}$. $\mathrm{SK}$ is a 414-residue protein containing three domains: SK $\alpha$ (aa1-144), SK $\beta$ (aa145-287), and SK $\gamma$ (aa 288414). SK isolated from different groups of streptococci or even within the isolates of the same groups shows a high degree of heterogeneity at gene and protein levels and results in variations in functional characteristic of SKs such as PA potencies and fibrin-specific activity $^{[9,11,12]}$. Identification of SK heterogeneity and its structure-dependent characteristics encouraged the identification of the functional regions in the SK domains for engineering more efficient $\mathrm{SKs}$ as a thrombolytic drug, especially for enhanced fibrindependent activity ${ }^{[10,13,14]}$. SK is the most cost-efficient drug of choice for thrombolytic therapy, particularly in developing countries, and improvement of its therapeutic properties is of high demand ${ }^{[4,10,13,14]}$. Studies have indicated that the heterogeneity is present in all domains, but the main source of SK variation is mainly in residues $147-218$ of $\beta$-domain, known as variable one region $(\mathrm{SK} \beta-\mathrm{V} 1)^{[11]}$. According to the phylogenic analysis of nucleotide sequences of SK $\beta$ V1, GAS-ska alleles are categorized into two main clusters with different functional features, cluster1 (SK1) and cluster2 (SK2), in which cluster2 is further subdivided into two subclusters, SK2a and SK2 $b^{[15,16]}$. Of note, SKs from GCS/GGS ( $s k c g$ ), which exhibit high PA activity in solution (similar to SK1), are categorized into SK2a cluster of the phylogenic tree, indicating the high similarity in the SK $\beta-\mathrm{V} 1$ of $s k c g$ and SK2a alleles ${ }^{[15,16]}$. Prior studies on functional properties of SK1 and SK2b have demonstrated that SK2b could activate Plg effectively when FG is present, whereas despite exhibiting higher PA potency, SK1 does not require $\mathrm{FG}$ for efficient Plg activation $^{[9,16,17]}$. In addition, domain-exchange studies between SK1 and SK2b exhibited the major contribution of $\mathrm{SK} \beta$ versus minor role of other domains $(\alpha / \gamma)$ in determining the PA potency ${ }^{[17,18]}$. In a recent comparative study, evaluation of the fibrindependent activity of recombinant SK form SK2a and SKC-H46A (the commercial source of therapeutic SK) has demonstrated that in the presence of FG, the PA activity of SK2a enhances several folds compared to that of the $\mathrm{SKC}^{[19]}$. However, in none of these prior studies, the fibrin-dependent activity or SK kinetics was/were addressed by domain-exchange strategies, especially in case of SK2a or $s k c g$ alleles.

We have recently reported the isolation of SK $(s \mathrm{~kg})$ with high PA activity from a GGS (SKG88) ${ }^{[20]}$. In the present study, using SKG88 (with high PA activity) and a well-known SK2a variants from GAS $\left(\mathrm{SK}_{\mathrm{STAB}}{ }\right)$ with low PA activity ${ }^{[21]}$, we evaluated the contribution of SK domains in kinetics and FG-bound$\mathrm{Plg}$ activation via "Molecular (SK $\beta)$ domain-exchange strategy" between SK genes of these two groups of streptococci.

\section{MATERIALS AND METHODS}

\section{Bacterial variants}

GAS (STAB902) and GGS (G88) with accession numbers CP007041.1 and HM390000.1, respectively were selected as the sources of SK for $\beta$-domain exchange. Based on DNA sequences of the variable region of $\mathrm{SK} \beta, \mathrm{SK}_{\mathrm{STAB} 902}$ and $\mathrm{SK}_{\mathrm{G} 88}$ have been reported as SK2a and SK2a co-clustered-skcg alleles, respectively ${ }^{[15,20,21]}$.

\section{Isolation of the SK genes and plasmid construction}

In the first step, to construct the recombinant parent SKs, the genomic DNA was isolated by DNA extraction kit (Qiagen, USA). The coding region of $s k$ gene (lacking the signal peptide sequence) was amplified by PCR using primers with inserted restriction sites for direct cloning into $\mathrm{pET} 26 \mathrm{~b}$ vector (forward primer: NdeI-SKf: 5'-GA CGAGACATATG ATTGCTGGACCTGAGTG-3'; reverse primer: XhoISKr 5'-GACACTCGAGTT TGTCGTTAGGGTTATC AG-3'; the sequences corresponding to restriction sites are underlined). Thermal program was set as 30 cycles of $95{ }^{\circ} \mathrm{C}$ for $1 \mathrm{~min}, 56{ }^{\circ} \mathrm{C}$ for $1 \mathrm{~min}$, and $72{ }^{\circ} \mathrm{C}$ for 3 min, which was followed by a final extension at $72{ }^{\circ} \mathrm{C}$ for $10 \mathrm{~min}$. The resulting amplified fragments were 
digested with $N d e I$ and XhoI and cloned into the same sites of pET26b expression vector downstream of $\mathrm{T} 7$ promoter and in tandem with the fused C-terminus $6 \times$ His-tag to yield two parent molecules, pET26b$\mathrm{SK}_{\mathrm{G} 88}$ and pET26b-SK $\mathrm{STAB902}_{\text {, }}$ (Fig. 1A). In the second step, to construct the chimeric molecules, the $\beta$-domain of parent SKs was exchanged. In this context, $\mathrm{SK}_{\mathrm{C}} \mathrm{S}$ $\left(\mathrm{SK}_{\mathrm{C} 1}\right.$ and $\left.\mathrm{SK}_{\mathrm{C} 2}\right)$ were constructed by BstEII/BsiWI digestion of the cloned genes in the parental constructs, from nucleotides 375 to 699 of $s k$ (the variable region of $\beta$-domain was composed of 109 residues) and crossligation of the resulting fragments (Fig. 1B). E. coli DH5 $\alpha$ cells were used for the propagation of plasmids. All cloning steps were performed according to standard procedures $^{[22]}$.

\section{Protein expression}

E. coli Rosetta strain (Novagen, USA) was used as an expression host for pET26b plasmids according to the manufacturer's protocol. Briefly, after the transformation of cells with the recombinant plasmids using the standard $\mathrm{CaCl}_{2}$ method, expression of protein was induced at $\mathrm{OD}_{600}$ of $0.5-0.6$ by IPTG to a final concentration of $1 \mathrm{mM}$. Cells were harvested by centrifugation after three hours of incubation at $37{ }^{\circ} \mathrm{C}$ and stored at $-20{ }^{\circ} \mathrm{C}$ for purification steps ${ }^{[22]}$.

\section{Protein purification}

The expressed SK proteins were purified under native conditions using Ni-NTA affinity chromategraphy according to manufacturer's protocol ${ }^{[23]}$. Briefly, the cell pellets were resuspended in a binding buffer $\left(50 \mathrm{mM}\right.$ of $\mathrm{NaH}_{2} \mathrm{PO}_{4}, 300 \mathrm{mM}$ of $\mathrm{NaCl}$, and 10 $\mathrm{mM}$ of imidazole) with $0.5 \mathrm{mg} / \mathrm{ml}$ lysozyme at $2-5 \mathrm{ml}$ per gram wet weight. Following incubation on ice for $30 \mathrm{~min}$, the cells were disrupted by sonication, and supernatant was collected after centrifugation at 10,000 $\times \mathrm{g}$ at $4{ }^{\circ} \mathrm{C}$ for 20-30 min. After the addition of $1 \mathrm{ml} \mathrm{Ni}-$ NTA resin to the clear lysate, the mixture was shaken at $4{ }^{\circ} \mathrm{C}$ for 60 minutes, loaded on column and washed four times with $4 \mathrm{ml}$ of wash buffer $(50 \mathrm{mM}$ of $\mathrm{NaH}_{2} \mathrm{PO}_{4}, 300 \mathrm{mM}$ of $\mathrm{NaCl}$, and $20 \mathrm{mM}$ of imidazole) and four times with $0.5 \mathrm{ml}$ of elution buffer $(50 \mathrm{mM}$ of $\mathrm{NaH}_{2} \mathrm{PO}_{4}, 300 \mathrm{mM}$ of $\mathrm{NaCl}$, and $250 \mathrm{mM}$ of imidazole).

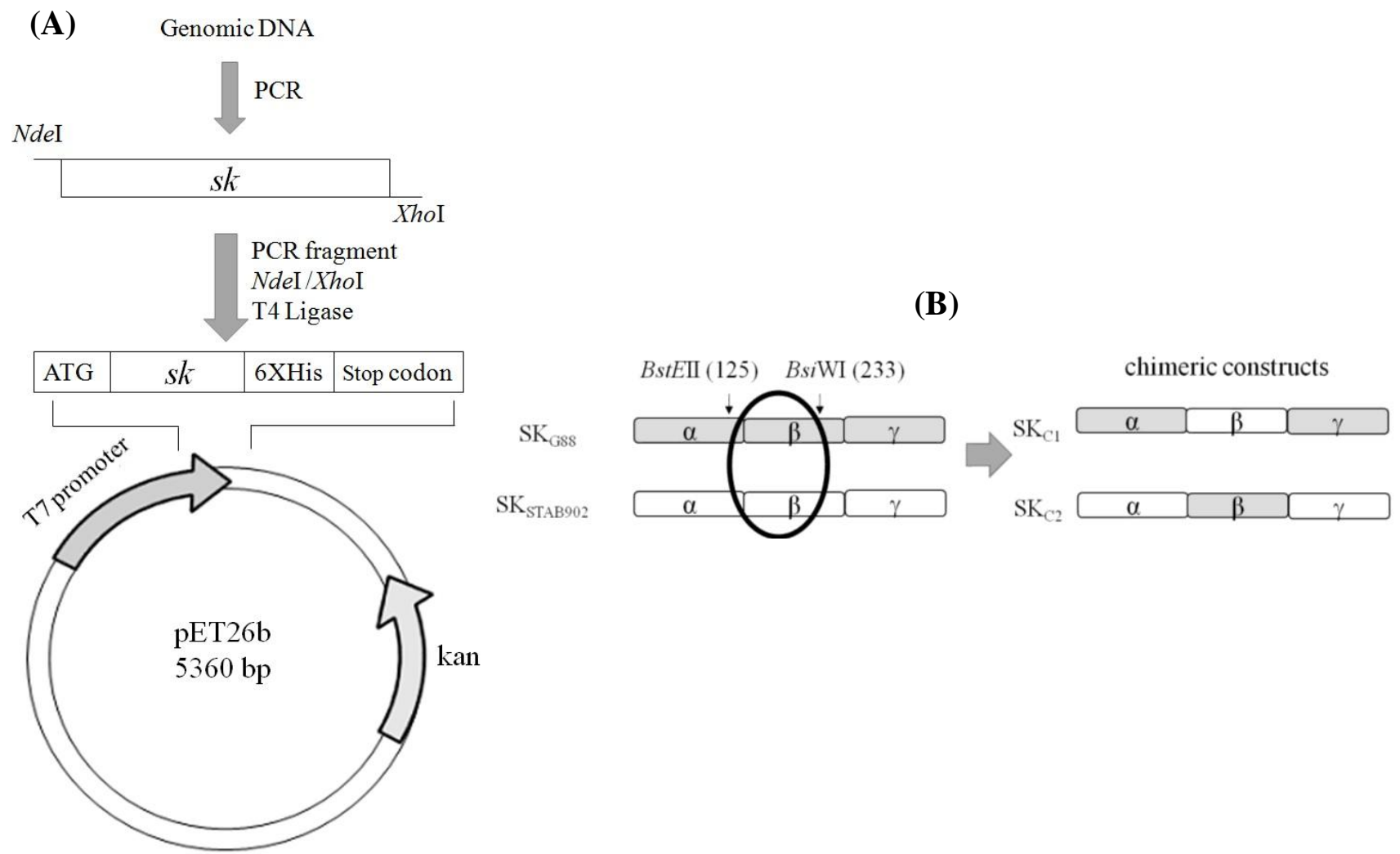

Fig. 1. (A) Schematic illustration for the insertion of $s k$ genes into pET26b. Fragments corresponding to $s k$ genes were digested with $N d e \mathrm{I}$ and $\mathrm{XhoI}$ and ligated with the vector pET26b. ATG, start translation codon derived from vector; $6 \times$ His-tag, the tag derived from the vector. (B) Construction of $\mathrm{SK}_{\mathrm{C}} \mathrm{s}$ by $\beta$-domain exchange (exchange of residues 125 through 233 between parental SKs). The unique restriction sites used for sequence exchange are indicated on parental $\mathrm{SKs}$. $\mathrm{SK}_{\mathrm{C} 1}$ and $\mathrm{SK}_{\mathrm{C} 2}$ are made by $\beta$-domain exchanges between $\mathrm{SK}_{\mathrm{G} 88}$ and $\mathrm{SK}_{\mathrm{STAB} 902}$. 


\section{SDS-PAGE and Western blot analysis}

The purity of purified SKs was analyzed on a $12 \%$ $(\mathrm{w} / \mathrm{v})$ SDS-PAGE gel, and the concentrations were determined by standard Bradford assay ${ }^{[22]}$ and $\mathrm{OD}_{280}$. For Western blotting, proteins were transferred to nitrocellulose membrane, and the membrane was blocked by 5\% BSA. Mouse anti-His monoclonal antibody (Qiagen) was used as the primary antibody, and HRP-labeled goat anti-mouse IgG (Qiagen) as the secondary (tracking) antibody. The bound antibodies were detected using 3,3-diaminobenzidine (Qiagen) ${ }^{[22]}$.

\section{Determination of SK activity}

The chromogenic assay is known as an approved internationally standard assay for SK activity (Third International Standard for SK, National Institute of Biological Standards and Controls, NIBSC, 2004, UK). SK activity was determined by using chromogenic substrate, a synthetic tripeptide H-D-valyl-L-leucyl-Llysine-p-nitroanilide dihydrochloride (S-2251; Sigma, USA $)^{[24]}$. Purified SK proteins $(100 \mathrm{nM})$ were added to a microtiter plate containing $1 \mathrm{mM}$ of S-2251 and 1 $\mu \mathrm{M}$ of Plg (Sigma) at $37{ }^{\circ} \mathrm{C}$ in a total volume of $100 \mu \mathrm{l}$ of the assay buffer (50 mM of Tris-HCl, $\mathrm{pH} 7.4$ ). Then hydrolysis of S-2251 was measured at $405 \mathrm{~nm}$ every 5 min for $60 \mathrm{~min}$ in a microplate reader (Synergy 4, UK). To determine fibrin-dependent activity, FG $(1 \mu \mathrm{M})$ was mixed in a 1:1 stoichiometric ratio with $\mathrm{Plg}(1 \mu \mathrm{M})$ and preincubated at $37^{\circ} \mathrm{C}$ for $15 \mathrm{~min}$. SKs $(100 \mathrm{nM})$ were added to the mixture, and the change in absorbance at $405 \mathrm{~nm}$ was measured at $37{ }^{\circ} \mathrm{C}$ after adding S-2251 (final concentration $1 \mathrm{mM}$ ). OD at $405 \mathrm{~nm}$ was plotted against time and activity rate (slope) was determined from linear portion of the curve. Serial dilutions of Streptase ${ }^{\circledR}$ (CSL, Behring, Germany), a commercially available standard SK, were used to prepare the standard calibration curve based on Hydrolysis of S2251 by $\mathrm{Plg}$, as described before ${ }^{[24]}$. All reactions were performed in triplicate ${ }^{[16]}$.

\section{Determination of kinetic constants}

For analyzing amidolytic parameters, stoichiometric concentrations of Plg and SK $(5.5 \mu \mathrm{M}$ SK and $5 \mu \mathrm{M}$ $\mathrm{Plg}$ ) were mixed in a 96-well microplate containing the assay buffer $(50 \mathrm{mM}$ Tris/ $\mathrm{HCl}, \mathrm{pH} 7.5)$ and incubated at $37^{\circ} \mathrm{C}$ for $5 \mathrm{~min}$ to construct the SK-PA complex. A suitable aliquot of the complex (final concentration, $100 \mathrm{nM}$ ) was transferred to the assay buffer along with various concentrations of $S 2251(0.1-1 \mathrm{mM})$ in a total volume of $100 \mu \mathrm{l}$. To determine the kinetic parameters for Plg activation (proteolytic kinetics), $100 \mathrm{nM}$ of SKs was added to the assay buffer containing $0.1 \mathrm{mM}$ of S2251 and varying concentrations of Plg (0.3 to 5.0 $\mu \mathrm{M})$. The reactions were carried out in a microplate reader at $37{ }^{\circ} \mathrm{C}$. The change in absorbance at $405 \mathrm{~nm}$ was monitored for $30 \mathrm{~min}$, and the initial reaction rates were obtained from plotting A405/min. The data were plotted as velocity over substrate concentration, and kinetic parameters of Plg activation were determined from Michaelis-Menten (V vs. S) kinetic and inverse (1/V vs. 1/S) Lineweaver-Burk plot using GraphPad Prism 8 (GraphPad Software, San Diego, USA) ${ }^{[20]}$.

\section{Statistical analyses}

Differences of SK activities and kinetic parameters among SK variants were determined using unpaired, two-tailed Student's $t$-test with $95 \%$ confidence intervals. Statistical analysis was carried out using SPSS software version 22.0 (SPSS, Inc., Chicago, IL). All linear regressions were performed applying GraphPad Prism 8, and $p$ values less than 0.05 were considered statistically significant.

\section{RESULTS}

\section{Cloning, expression, and purification of SK}

Using the $s k f$ and $s k r$ primers and genomic DNA as emplate, PCR reactions resulted in a single band of the expected length (1250 bp) of $s k$ gene (Fig. 2A). Cloning steps for the insertion of $s k$ gene in pET26b vector is illustrated in Figure $1 \mathrm{~A} . \mathrm{SK}_{\mathrm{C}} \mathrm{S}\left(\mathrm{SK}_{\mathrm{C} 1}\right.$ and $\mathrm{SK}_{\mathrm{C} 2}$ ) were constructed by the exchange of DNA fragments encoding the 125-233 residue fragments between two parent molecules (Fig. 1B). Restriction enzyme analysis of the recombinant vectors harboring $s k$ genes (Fig. 2B, 2C, and 2D) and nucleotide sequence analysis (not shown) confirmed the accuracy of cloning procedures. The recombinant parent and chimeric proteins were verified by SDS-PAGE (Fig. $3 \mathrm{~A}$ and $3 \mathrm{~B}$ ) and Western blotting analyses and the results (Fig. 3D) indicated the presence of the full length protein with expected molecular weight of 47 $\mathrm{kDa}$. Induction of protein expressions in large-scale cultures $(50 \mathrm{ml})$ and purification of His-tagged SK proteins using Ni-NTA affinity chromatography finally provided us with approximately $5 \mathrm{mg}$ of full length proteins with a purity of more than $90 \%$ for each protein that was shown by SDS-PAGE (Fig. 3C).

\section{The steady-state kinetic constants for amidolytic activity}

To evaluate the contribution of SK $\beta$ on nonproteolytic formation of SK.Plg* complex, the amidolytic activity of SK.Plg* activator complex was studied. The hydrolysis of substrate S2251 by SK/Plg* complex is a measure of non-proteolytic activity. The kinetic parameters, including substrate affinity $\left(\mathrm{K}_{\mathrm{m}}\right)$, 
(A)

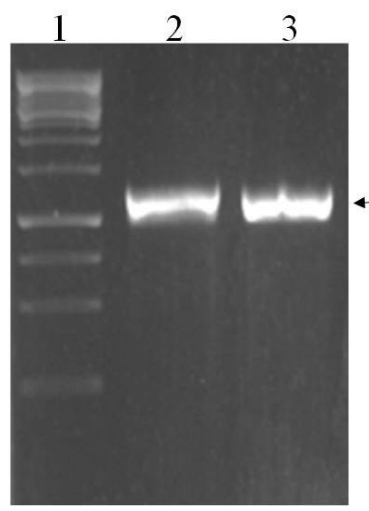

(B)

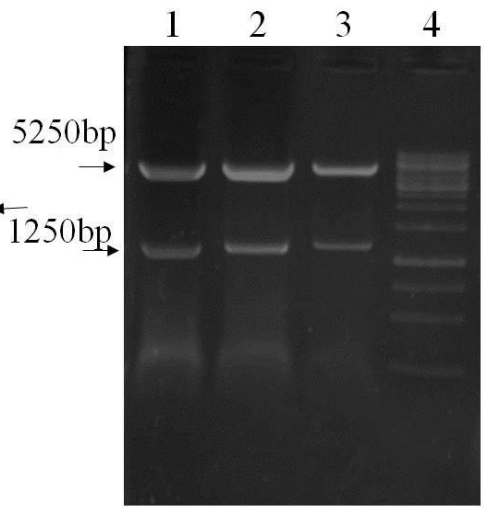

(C)

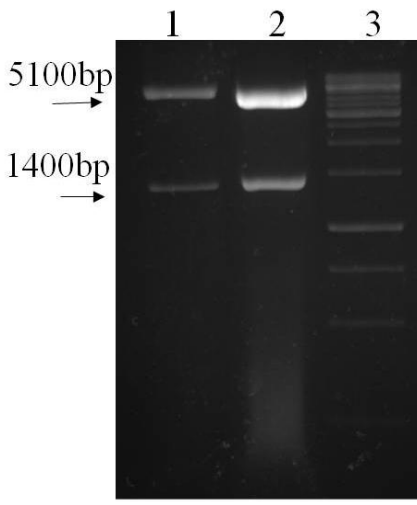

(D)

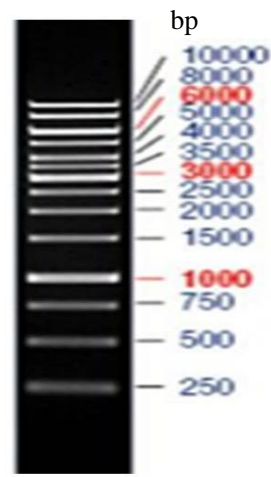

Fig. 2. Agarose gel (1\%) of amplified $s k$ genes and restriction analysis of recombinant pET26b-SKs. (A) The coding region of $s k$ gene (lacking the signal peptide sequence) was amplified by PCR using primers with inserted restriction sites for direct cloning into pET26b vector. PCR reactions resulted in a single band of the expected length (1250 bp) of $s k$ gene. Lane1, DNA marker, Lanes 2 and 3 , PCR products of $s k g 88$ and skstab902 genes from genomic DNA. (B) Restriction enzyme analysis of the recombinant vector pET26b-SKG 88 , pET26b-SK $\mathrm{STAB902}_{\text {, and pET26b-SK }}$ by NdeI-XhoI yielded 5250 and $1250 \mathrm{bp}$ fragments corresponding to vector and PCR fragments (Lanes 1, 2, and 3, respectively); Lane 4, DNA marker; (C) digested pET26b-SKG 88 and pET26b-SK STAB902 $_{\text {by } B s t E I I}$ produced two bands with the size of 1400 and $5100 \mathrm{bp}$ (Lanes 1 and 2, respectively); lane 3, DNA marker; (D) The size and pattern of DNA markers. The corresponding bands are indicated by arrows, and the sizes of the bands of DNA marker are illustrated on the right. DNA marker (1 kb; Thermo Fisher Scientific SM0311, USA)

catalytic activity $\left(\mathrm{K}_{\mathrm{cat}}\right)$, and the constant of catalytic efficiency $\left(\mathrm{K}_{\mathrm{cat}} / \mathrm{K}_{\mathrm{m}}\right.$; efficiency of the Plg conversion into plasmin) were measured (Table 1). As shown in Table 1, $\beta$-domain exchange did not influence the catalytic efficiencies of resultant chimeras significantly; $\mathrm{K}_{\mathrm{m}}$ of $\mathrm{SK}_{\mathrm{C} 1}$ (G88-STAB-G88) decreased only $10 \%$ (from $0.41 \mathrm{mM}$ of parent $\mathrm{SK}_{\mathrm{G} 88}$ to 0.36 $\mathrm{mM}$ ); furthermore, the $\mathrm{K}_{\mathrm{cat}}$ attenuated $10 \%$ compared to that of the parent $\mathrm{SK}_{\mathrm{G} 88}$ (from $83.33 \mathrm{~min}^{-1}$ of parent
$\mathrm{SK}_{\mathrm{G} 88}$ to $74.93 \mathrm{~min}^{-1}$ ), which resulted in almost equal catalytic efficiency (204.99 vs. $\left.205.84 \mathrm{~min}^{-1} / \mathrm{mM}\right)$. Likewise, while the $\mathrm{K}_{\mathrm{m}}$ of $\mathrm{SK}_{\mathrm{C} 2}$ (STAB-G88-STAB) increased $9 \%$ ( 0.39 vs. $0.36 \mathrm{mM})$ and the $\mathrm{K}_{\text {cat }}$ enhanced $20 \%$ relative to the parent molecule, $\mathrm{SK}_{\mathrm{STAB} 902}$ (from $30.93 \mathrm{~min}^{-1}$ to $36.96 \mathrm{~min}^{-1}$ ) resulted in only $10 \%$ raise of catalytic efficiency (94.58 vs. $86.09 \mathrm{~min}^{-1} / \mathrm{mM} ; p<$ 0.05 ; Table 1.
(A)

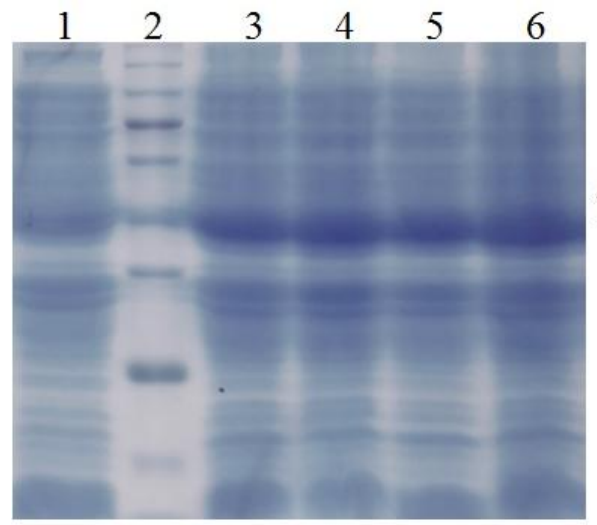

(B)

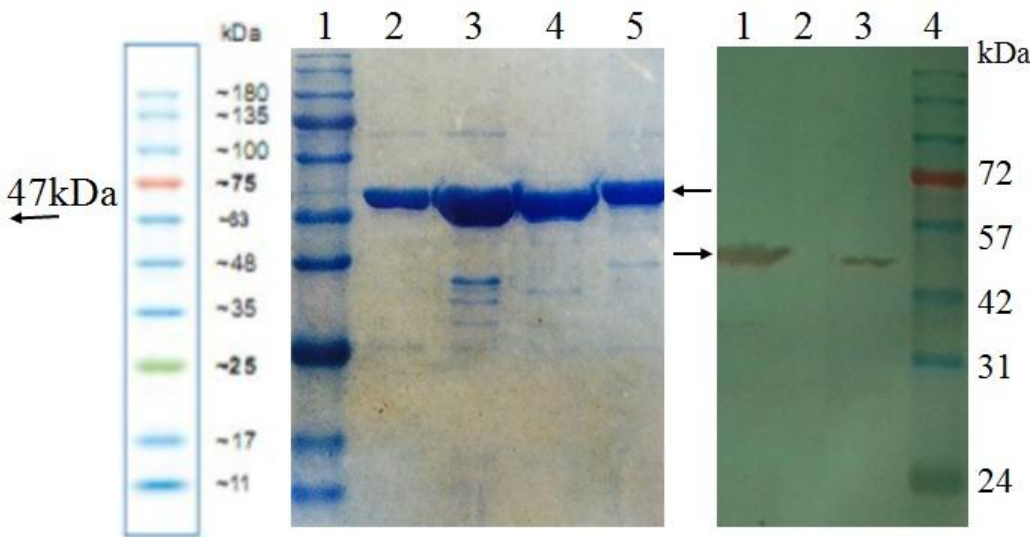

Fig. 3. Analysis of expressed proteins by SDS-PAGE and Western blotting. (A) SDS-PAGE (12\%) of total protein extracted from $E$. coli Rosetta/pSK ${ }_{\mathrm{G} 88}$ cells. Lane 1 corresponds to uninduced bacterial cells; lane 2, protein marker 10-180 kDa (SM7012 CinnaGen, Iran); lane 3-6, total protein extracted from IPTG $(1 \mathrm{mM})$ induced E. coli Rosetta/pSK $\mathrm{G}_{\mathrm{G} 8}, \mathrm{pSK}_{\mathrm{STAB} 902 \text {, }}$ and $\mathrm{pSK}_{\mathrm{Cl}-2}$ cells, respectively. (B) The size and pattern of the bands of protein marker 10-180 kDa. (C) Analysis of purified proteins by SDS-PAGE (12\%). Lane 1, molecular weight marker; lanes 2-5, purified $\mathrm{SK}_{\mathrm{G} 88}, \mathrm{SK}_{\mathrm{STAB} 902}, \mathrm{SK}_{\mathrm{C} 1}$, and $\mathrm{SK}_{\mathrm{C} 2}$ proteins, respectively. (D) Western-blot analysis of $\mathrm{SK}_{\mathrm{C} 1}$ and $\mathrm{SK}_{\mathrm{C} 2}$ proteins. Lanes 1 and 3, crude lysis of E. coli Rosetta cells expressing $\mathrm{SK}_{\mathrm{C} 1}$ and $\mathrm{SK}_{\mathrm{C} 2}$, respectively after induction by IPTG (1 mM); lane 2, crude lysis of $E$. coli Rosetta cells before induction (no band was observed); lane 4, molecular weight marker. The arrows indicate the band of $47 \mathrm{kDa}$ SK. 
Table 1. The amidolytic and proteolytic kinetic parameters of SK variants

\begin{tabular}{|c|c|c|c|c|c|c|}
\hline \multirow[b]{2}{*}{$\begin{array}{c}\text { SK } \\
\text { variants }\end{array}$} & \multicolumn{3}{|c|}{ Amidolytic constants ${ }^{a}$} & \multicolumn{3}{|c|}{ Proteolytic constants ${ }^{b}$} \\
\hline & $\begin{array}{c}\mathrm{Km} \\
(\mathrm{mM})\end{array}$ & $\begin{array}{c}\mathrm{K}_{\text {cat }} \\
\left(\mathrm{min}^{-1}\right)\end{array}$ & $\begin{array}{c}\mathbf{K}_{\text {cat }} / \mathbf{K}_{\mathrm{m}} \\
\left(\mathrm{min}^{-1} / \mathbf{m M}\right)\end{array}$ & $\begin{array}{c}\mathbf{K}_{\mathrm{m}} \\
(\mu \mathrm{M})\end{array}$ & $\begin{array}{c}\mathbf{K}_{\text {cat }} \\
\left(\mathrm{min}^{-1}\right)\end{array}$ & $\begin{array}{c}\mathbf{K}_{\text {cat }} / \mathbf{K}_{\mathrm{m}} \\
\left(\mathrm{min}^{-1} / \mu \mathrm{M}\right)\end{array}$ \\
\hline $\mathrm{SK}_{\mathrm{G} 88}$ & $0.41 \pm 0.006$ & $83.33 \pm 2.82$ & 204.99 & $0.77 \pm 0.004$ & $19.82 \pm 4.20$ & 25.67 \\
\hline $\mathrm{SK}_{\mathrm{STAB} 902}$ & $0.36 \pm 0.007$ & $30.93 \pm 0.78$ & 86.09 & $4.15 \pm 0.72$ & $10.64 \pm 1.25$ & 2.56 \\
\hline $\mathrm{SK}_{\mathrm{C} 1}$ & $0.36 \pm 0.026$ & $74.93 \pm 3.58$ & 205.84 & $1.09 \pm 0.13$ & $22.59 \pm 5.02$ & 20.70 \\
\hline $\mathrm{SK}_{\mathrm{C} 2}$ & $0.39 \pm 0.063$ & $36.96 \pm 3.75$ & 94.58 & $3.73 \pm 1.23$ & $11.68 \pm 4.68$ & 3.12 \\
\hline
\end{tabular}

${ }^{\mathrm{a}}$ The amidolytic kinetic parameters of SK variants were determined by pre-complexing equimolar ratios of SK and Plg. ${ }^{\mathrm{b}}$ For measurements of proteolytic activities, stoichiometric activator complexes of SK.Plg* were formed by mixing Plg and SK variants. Kinetic parameters including substrate affinity $\left(\mathrm{K}_{\mathrm{m}}\right)$, catalytic activity $\left(\mathrm{K}_{\text {cat }}\right)$, and the constant of catalytic efficiency $\left(\mathrm{K}_{\mathrm{cat}} / \mathrm{K}_{\mathrm{m}}\right)$ of Plg activation were calculated from Michaelis-Menten (V vs. S) kinetic and inverse (1/V vs. 1/S) Lineweaver-Burk plots using GraphPad Prism 8 software. All measured $p$ values were less than 0.05 and considered significant. The Table indicates the minimal alteration of amidolytic kinetic parameters, while the proteolytic constants changed more significantly, especially in case of $\mathrm{K}_{\mathrm{m}}$.

\section{Steady-state kinetic constants for proteolytic activity}

The proteolytic activity of SK variants after equimolar SK.Plg complex formation was assayed against a concentration range of substrate Plg. As shown in Table 1 , the $\mathrm{K}_{\mathrm{m}}$ of $\mathrm{SK}_{\mathrm{C} 1}$ raised 1.5fold (1.09 vs. $0.77 \mu \mathrm{M}$ ), and the $\mathrm{K}_{\mathrm{cat}}$ raised $13 \%$ (22.59 vs. 19.82 $\min ^{-1}$ ) compared with that of $\mathrm{SK}_{\mathrm{G} 88}$ that led to $20 \%$ lower catalytic efficiency (from 25.67 of parent $\mathrm{SK}_{\mathrm{G} 88}$ decreased to $\left.20.70 \mathrm{~min}^{-1} / \mu \mathrm{M}\right)$. The proteolytic constants of $\mathrm{SK}_{\mathrm{C} 2}$ were also altered relative to the parent $\mathrm{SK}_{\mathrm{STAB} 902}$. The catalytic efficiency of $\mathrm{SK}_{\mathrm{C} 2}$ increased $20 \%\left(3.12\right.$ vs. $\left.2.56 \mathrm{~min}^{-1} / \mu \mathrm{M}\right)$, since the $K_{m}$ decreased $10 \%(3.73$ vs. $4.15 \mu \mathrm{M})$ and the $\mathrm{K}_{\mathrm{cat}}$ raised $10 \%$ (11.68 vs. $\left.10.64 \mathrm{~min}^{-1}\right)$ compared with those of $\operatorname{SK}_{\text {STAB902 }}(p<0.05$; Table 1$)$. These alterations were in accordance with the change of specific activities and imply that $\beta$-domain exchange influences the conformational and functional changes of SK yielding alteration of the kinetic constants of proteolytic pathway and conversion of Plg substrate to plasmin, which led to different activities of SK variants.

\section{SK activity in absence/presence of FG}

Employing chromogenic substrate S-2251, the change in absorbance at $405 \mathrm{~nm}$ was measured as a function of time. As shown in Figure 4 and Table 2, the activation rate of all constructs raised significantly in the presence of FG, but with different order of magnitudes. The activation rates of constructs owning SK2aß, namely $\mathrm{SK}_{\mathrm{STAB} 902}$ and $\mathrm{SK}_{\mathrm{C} 1}$, showed 6.1 and 5.7fold increase (0.55 and 2.43 vs. 0.09 and 0.43 ), whereas the activation rates of the constructs owning skcg $\beta$, namely $\mathrm{SK}_{\mathrm{G} 88}$ and $\mathrm{SK}_{\mathrm{C} 2}$, enhanced 3.5 and 4.5fold (2.0 and 0.5 vs. 0.57 and 0.11 ), respectively in the presence of $1 \mu \mathrm{M}$ FG. It is worth mentioning that as expected, the stimulatory effect of FG on SK2a was greater than skcg allele, and the activity of $\mathrm{SK}_{\mathrm{C} 1}$ in the presence of FG was more than that of $\mathrm{SK}_{\mathrm{G} 88}(p<0.05)$.

\section{DISCUSSION}

The rationale for performing the present study was to gain insights into the degree of fibrin dependency and kinetic differences of $\mathrm{SK}_{\mathrm{G} 88}$ from group $\mathrm{G}$ streptococci ( $s k c g$ allele) compared with the $\mathrm{SK}_{\mathrm{STAB} 902}$ from cluster $2 \mathrm{a}$, group A streptococci, and the role of $\beta$-domain in these characteristics. To the best of our knowledge, there is no prior study on the role of $\beta$-domain in fibrin-dependent mode of action or SK kinetics by domain-exchange strategies, especially for SK2a or $s k c g$ alleles. Our results confirmed the higher increase in SK activities of $\mathrm{SK}_{\mathrm{STAB} 902}$ than $s k c g$ allele in the presence of FG and indicated the major contribution of $\beta$-domain in conferring this feature, which might lead

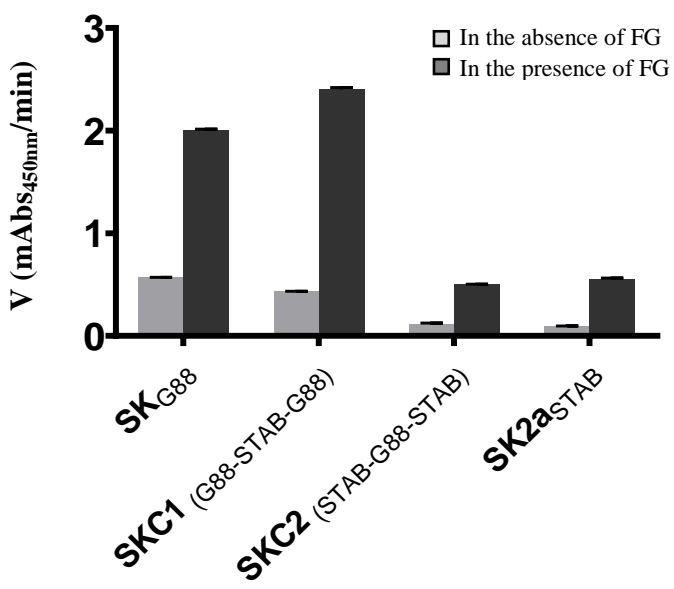

Fig. 4. The Plg activation rates of various SKs in the presence and absence of FG. The activation rates were measured by monitoring the absorbance at $450 \mathrm{~nm}$ and calculated by linear regression from the linear regions of plots A405 nm vs. time (t). The activation rates of all constructs improved several orders of magnitude. Notably, FG stimulated significantly $(p<0.05)$ the activity of SK2a $\beta$ containing $\mathrm{SK}_{\mathrm{STAB} 902}$ and $\mathrm{SK}_{\mathrm{C} 1}$ more efficiently than that of $s k c g$. $\mathrm{SK}_{\mathrm{G} 88}$ and $\mathrm{SK}_{\mathrm{STAB} 902}$ are the parental and $\mathrm{SK}_{\mathrm{C} 1}$ and $\mathrm{SK}_{\mathrm{C} 2}$ are the chimeric constructs produced by $\beta$ domain exchange. 
Table 2. PA activity in the absence and presence of FG

\begin{tabular}{cccc}
\hline $\begin{array}{c}\text { Parent/ } \\
\mathbf{S K}\end{array} \mathbf{C}$ & $\begin{array}{c}\text { PA activity in the } \\
\text { absence of } \mathbf{F G}\left(\mathbf{\Delta} \mathbf{O} \mathbf{D}_{\mathbf{4 0 5}} / \mathbf{t}\right)\end{array}$ & $\begin{array}{c}\text { PA activity in the } \\
\text { presence of } \mathbf{F G}\left(\mathbf{\Delta} \mathbf{O} \mathbf{D}_{\mathbf{4 0 5}} / \mathbf{t}\right)\end{array}$ & $\begin{array}{c}\text { Fold increase of activity } \\
\text { in the presence of } \mathbf{F G}\end{array}$ \\
\hline $\mathrm{SK}_{\mathrm{G} 88}$ & $0.57 \pm 0.002$ & $2.0 \pm 0.015$ & 3.5 \\
$\mathrm{SK}_{\mathrm{STAB} 92}$ & $0.09 \pm 0.006$ & $0.55 \pm 0.03$ & 6.1 \\
$\mathrm{SK}_{\mathrm{C} 1}$ & $0.43 \pm 0.006$ & $2.43 \pm 0.02$ & 5.7 \\
$\mathrm{SK}_{\mathrm{C} 2}$ & $0.11 \pm 0.001$ & $0.5 \pm 0.003$ & 4.5 \\
\hline
\end{tabular}

to designing fibrin-specific generations of SK. As shown in Figures $2 \mathrm{~A}$ and 3, results of PCR and SDSPAGE/Western blot analyses indicated the expected length (1250 bp) of $s k$ gene and SK protein $(47 \mathrm{kDa})$, which is in agreement with prior molecular isolation and expression studies for SK (reviewed in ${ }^{[10]}$ ).

According to kinetic results (Table 1), the $\beta$-domain exchange did not cover any significant alteration in the amidolytic catalytic efficiency $\left(\mathrm{K}_{\mathrm{cat}} / \mathrm{K}_{\mathrm{m}}\right)$ of SK.Plg* activator complexes of the $\mathrm{SK}_{\mathrm{C}} \mathrm{S}\left(\mathrm{SK}_{\mathrm{C} 1}\right.$ and $\left.\mathrm{SK}_{\mathrm{C} 2}\right)$ compared to their parental SKs. Indeed, these results revealed a major role for $\alpha / \gamma$-domains in determination of amidolytic activity, which is consistent with several prior reports on the potential role of $\alpha / \gamma$-domains in interaction with Plg and formation of the SK.Plg* activator complexes ${ }^{[25-29]}$. In this context, the critical role of Ile1 in $\alpha$-domain of SK for the formation of SK.Plg* activator complex through establishing a salt bridge with Asp741 of Plg, which is essential for the induction of an active site in Plg is emphasized ${ }^{[27]}$. In addition, a surface-exposed loop in residues 88-97 of $\alpha$-domain has been also reported. This loop not only is involved in SK.Plg* activator complex formation but also interacts with the catalytic domain of $\mathrm{Plg}$ (microplasmin). Thus, this behavior might have a crucial role in catalytic turnover of the substrate Plg while minimally affecting enzyme-substrate affinity $^{[25,26]}$. Accordingly, the potential key role of Arg324, Asp325, Lys332, and Lys334 as well as residues between $314-342$ in the $\gamma$-domain for the amidolytic activity of the SK.Plg* activator complex has been proposed ${ }^{[28,29]}$.

The $\mathrm{K}_{\mathrm{cat} /} \mathrm{K}_{\mathrm{m}}$ values of proteolytic activity (as an indicator for the efficiency of conversion of substrate $\mathrm{Plg}$ into plasmin) for $\mathrm{SK}_{\mathrm{C} 1}$ and $\mathrm{SK}_{\mathrm{C} 2}$ compared to parental SKs showed more significant alterations compared to the amidolytic efficiency (Table 1). Of note, the $\mathrm{K}_{\mathrm{m}}$ values, which show the substrate affinity, were affected more significantly compared to the $\mathrm{K}_{\mathrm{cat}}$, indicating the catalytic turnover (which implies the important role of the exchanged segment in affinity of the activator complex to substrate Plg). Our finding is in accordance with several studies addressing the importance of $\mathrm{SK} \beta$ in the proteolytic activity of SK. Indeed, by bridging the $\mathrm{SK} \alpha$ and $\mathrm{SK} \gamma, \mathrm{SK} \beta$ mediates high affinity interaction between $\mathrm{SK}$ and $\mathrm{Plg}^{[20,30-32]}$. This domain seems to involve in high-affinity interactions between SK and Plg substrate, as well as strong binding of Plg substrate to the proteolytic complex and efficient conversion of Plg substrate to plasmin $^{[31]}$. Our results are in line with reports on the critical role of loop 170 of SK $\beta$ in mediating catalytic turnover of the substrate Plg (indicated by $\mathrm{K}_{\text {cat }}$ of the proteolytic pathway) ${ }^{[8,25]}$. In further support of our results, the role of loop 250 in SK $\beta$ for Plg recognition by active SK.Plg* complex and Plg docking has also been suggested ${ }^{[32]}$. It should be noted, however, that several residues in other domains of SK, like residues 314-347 and 285-414 of SK $\gamma$, have been proposed for contribution in the processing of Plg by the SKplasmin complex and catalytic activation of $\mathrm{Plg}^{[28]}$.

In general, the presence of FG enhanced the activity of all SKs, but its effect was around two times higher for $\mathrm{SK} 2 \mathrm{a} \beta$ containing $\mathrm{SK}_{\mathrm{STAB} 902} / \mathrm{SK}_{\mathrm{C} 1}$ than $\mathrm{skcg} \beta$ containing $\mathrm{SK}_{\mathrm{G} 88} / \mathrm{SK}_{\mathrm{C} 2}$ proteins $(6.1 / 5.7$ vs. 3.5/4.5fold enhancement of activity, respectively; Fig. 4 and Table 2 ). These results accord with prior reports on generally positive effect of the binding of FG to Plg to change its conformation in favor of enhanced activation of $\mathrm{Plg}^{[16,19,33]}$, which has been higher for GAS-SK2a variants compared to $s k c-\mathrm{SK}$ from $\mathrm{GCS}^{[19]}$. In further agreement, it has also been reported that the PA activity of SK1 and SK2b variants enhances 1.2-1.8 and 10-18fold, respectively in the presence of $\mathrm{FG}^{[33]}$. However, in these prior studies, the role of SK domains or special residues on this property was not elucidated. Identification of the SK domains involved in FGbound-Plg activation might help to improve the fibrinspecific characteristics of SK for therapeutic purposes ${ }^{[13]}$. Consistent with a recent study, $\mathrm{SK}_{\mathrm{G} 88}$, as represented in Figure 4, showed high intrinsic FG-bound-Plg activation ${ }^{[20]}$, which was about fourfold higher than $\mathrm{SK}_{\mathrm{STAB}}$ 902. Interestingly, this high FG-bound-Plg activation further enhanced in $\mathrm{SK}_{\mathrm{Cl}}$, while in the absence of $\mathrm{FG}, \mathrm{PA}$ potency of $\mathrm{SK}_{\mathrm{C} 1}$ was still lower than the parental $\mathrm{SK}_{\mathrm{G} 88 \text {. Of }}$ note, these characteristics of $\mathrm{SK}_{\mathrm{C} 1}$ might be of interest for development of a fibrin-specific version of SK for targeted fibrinolysis ${ }^{[13]}$. Collectively, these observations might indicate both the contribution of 
SK2a 3 of $\mathrm{SK}_{\mathrm{STAB} 9023}$ and $\mathrm{SK} \alpha \gamma$ of $s k c g\left(\mathrm{SK}_{\mathrm{G} 88}\right)$ in PA properties of $\mathrm{SK}_{\mathrm{C} 1}$. Almost the same justification might be considered for $\mathrm{SK}_{\mathrm{C} 2}$ compared to the parental SKs, which implys the collaborative contributions of $\beta$ - and $\alpha \gamma$-domains in FG-bound-Plg activation and agrees with proposed negative role of the first 59 residues of $\mathrm{SK} \alpha$ in fibrin-dependent mode of the SK action ${ }^{[34]}$.

Taken together, by molecular exchanging SK $\beta$ domains between groups G and A (SK2a) streptococci and recombinant expression of the two $\mathrm{SK}_{\mathrm{C}} \mathrm{S}$ and two parental SKs, we could assess and compare the kinetics and FG-bound-Plg activation of the four SKs to gain insights into the role of $\operatorname{SK} \beta$ and SK $\alpha \gamma$ in these functional characteristics. To our best of knowledge, this is the first report on domain exchange study between groups $\mathrm{G}$ and $\mathrm{A}$ streptococci. Our results indicated the minor role of SK $\beta$ compared to SK $\alpha \gamma$ in fibrin-independent amidolytic activity, while the reverse was demonstrated for fibrin-dependent proteolytic activity and FG-bound-Plg activation. The obtained data might be of interest for engineering and development of a fibrin-specific version of SK for targeted fibrinolysis and thrombolytic therapy.

\section{ACKNOWLEDGMENTS}

This work was financially supported by Pasteur Institute of Iran in partial fulfillment of Ph.D. thesis of M.R. in a medical Biotechnology program.

CONFLICT OF INTEREST. None declared.

\section{REFERENCES}

1. Shabbir M, Ahmad A. Campaign-once again streptokinase trials (COAST) in acute ischemic stroke. Journal of stroke and cerebrovascular diseases 2018; 27(3): 819-820.

2. Khasa AaYP. The evolution of recombinant thrombolytics: Current status and future directions. Bioengineered 2017; 8(4): 331-358.

3. Bade AS, Shaikh SSA, Khemani H, Singh G, Bansal NOJCr. Thrombolysis is an effective and safe therapy in suck mitral valves with delayed presentation as well as hemodynamically unstable patients: A single centre study. Cardiology research 2018; 9(3): 161-164.

4. Keramati M, Arabi Mianroodi R, Memarnejadian A, Mirzaie A, Sazvari S, Mehdi Aslani M, Roohvand F. Towards a superior streptokinase for fibrinolytic therapy of vascular thrombosis. Cardiovascular and hematological agents in medicinal chemistry 2013; 11(3): 218-229.

5. Maheshwari N, Kantipudi S, Maheshwari A, Arora K, Vandana, Kwatra N, Sahni G. Amino-terminal fusion of epidermal growth factor 4,5,6 domains of human thrombomodulin on streptokinase confers antireocclusion characteristics along with plasmin-mediated clot specificity. PLoS one 2016; 11(3): e0150315.

6. Lal V. Fibrinolytic drug therapy in the management of intravascular thrombosis, especially acute myocardial infarction-A Review. journal of pharmacology and clinical research 2017; 2(4): DOI: 10.19080/JPCR. 2017.02.555593.

7. Boxrud PD, Fay WP, Bock PE. Streptokinase binds to human plasmin with high affinity, perturbs the plasmin active site, and induces expression of a substrate recognition exosite for plasminogen. Journal of biological chemistry 2000; 275(19): 14579-14589.

8. Aneja R, Datt M, Yadav S, Sahni G. Multiple exosites distributed across the three domains of streptokinase cooperate to generate high ctalytic rates in the streptokinase-plasmin activator complex. Biochemistry 2013; 52(49): 8957-8968.

9. Cook SM, Skora A, Gillen CM, Walker MJ, McArthur JD. Streptokinase variants from $\mathrm{S}$ treptococcus pyogenes isolates display altered plasminogen activation characteristics-implications for pathogenesis. Molecular microbiology 2012; 86(5): 1052-1062.

10. Kunamneni A, Durvasula R. Streptokinase-A drug for thrombolytic therapy: a patent review. Recent advances in cardiovascular drug discovery 2014; 9(2): 106-121.

11. Huang TT, Malke H, Ferretti JJ. Heterogeneity of the streptokinase gene in group A streptococci. Infection and immunity 1989; 57(2): 502-506.

12. Johnston KH, Chaiban J, Wheeler RJG. Analysis of the Variable Domain of the Streptokinase Gene from Group A streptococcus by the Polymerase Chain Reaction. In: Cleary P. (ed.), Genetics and Molecular Biology of Streptococci Lactococci, and Enterococci. Washington DC, American Society for Microbiology; 1991. p. 190194.

13. Sazonova IY, McNamee RA, Houng A, King S, Hedstrom L, Reed GL. Reprogrammed streptokinases develop fibrin-targeting and dissolve blood clots with more potency than tissue plasminogen activator. Journal of thrombosis and haemostasis 2009; 7(8): 1321-1328.

14. Klegerman ME. Translational initiatives in thrombolytic therapy. Frontiers of medicine 2017; 11(1): 1-19.

15. Kalia A, Bessen DE. Natural selection and evolution of streptococcal virulence genes involved in tissue-specific adaptations. Journal of bacteriology 2004; 186(1): 110121.

16. McArthur JD, McKay FC, Ramachandran V, Shyam P, Cork AJ, Sanderson-Smith ML, Cole JN, Ringdahl U, Sjöbring U, Ranson M. Allelic variants of streptokinase from Streptococcus pyogenes display functional differences in plasminogen activation. The FASEB journal 2008; 22(9): 3146-3153.

17. Zhang Y, Mayfield JA, Ploplis VA, Castellino FJ. The $\beta$-domain of cluster $2 \mathrm{~b}$ streptokinase is a major determinant for the regulation of its plasminogen activation activity by cellular plasminogen receptors. Biochemical and biophysical research communication. 2014; 444(4): 595-598.

18. Zhang Y, Liang Z, Glinton K, Ploplis VA, Castellino FJ. 
Functional differences between Streptococcus pyogenes cluster 1 and cluster $2 \mathrm{~b}$ streptokinases are determined by their $\beta$-domains. FEBS letters 2013; 587(9): 1304-1309.

19. Huish $\mathrm{S}$, Thelwell $\mathrm{C}$, Longstaff $\mathrm{C}$. Activity regulation by fibrinogen and fibrin of streptokinase from Streptococcus pyogenes. PloS one 2017; 12(1): e0170936.

20. Keramati M, Aslani MM, Khatami S, Roohvand F. Sequence and kinetic analyses of streptokinase from two group $\mathrm{G}$ streptococci with high fibrin-dependent plasminogen activities and the identification of novel altered amino acids as potential hot spots. Biotechnology letters 2017; 39(6): 889-895.

21. Soriano N, Vincent P, Moullec S, Meygret A, Lagente V, Kayal S, Faili A. Closed genome sequence of noninvasive Streptococcus pyogenes M/emm3 strain STAB902. Genome announcements 2014; 2(4): e00792e00714.

22. Sambrook J, Russell DW. The Condensed Protocols from Molecular Cloning: a Laboratory Manual. New York: Cold Spring Harbor Laboratory Press; 2006.

23. QIAexpressionist A. A Handbook for High-Level Expression and Purification of $6 \times$ his-tagged proteins. Fifth edition. Qiagen; 2003.

24. Wohl RC, Summaria L, Robbins KC. Kinetics of activation of human plasminogen by different activator species at $\mathrm{pH} 7.4$ and 37 degrees C. Journal of biological chemistry 1980; 255(5): 2005-2013.

25. Aneja R, Datt M, Singh B, Kumar S, Sahni G. Identification of a new exosite involved in catalytic turnover by the streptokinase-plasmin activator complex during human plasminogen activation. Journal of biological chemistry 2009; 284(47): 32642-32650.

26. Yadav S, Datt M, Singh B, Sahni G. Role of the 88-97 loop in plasminogen activation by streptokinase probed through site-specific mutagenesis. Biochimica et biophysica acta 2008; 1784(9): 1310-1318.

27. Mundada LV, Prorok $M$, DeFord ME, Figuera $M$, Castellino FJ, Fay WP. Structure-function analysis of the streptokinase amino terminus (residues 1-59).
Journal of biological chemistry 2003; 278(27): 2442124427.

28. Wang X, Lin X, Loy JA, Tang J, Zhang XC. Crystal structure of the catalytic domain of human plasmin complexed with streptokinase. Science 1998; 281(5383): $1662-1665$

29. Wu DH, Shi GY, Chuang WJ, Hsu JM, Young KC, Chang CW, Wu HL. Coiled coil region of streptokinasedomain is essential for plasminogen activation. The journal of biological chemistry 2001; 276(18): 1502515033.

30. Gladysheva IP, Sazonova IY, Chowdhry SA, Liu L, Turner RB, Reed GL. Chimerism reveals a role for the streptokinase $\beta$-domain in nonproteolytic active site formation, substrate, and inhibitor interactions. Journal of biological chemistry 2002; 277(30): 26846-26851.

31. Tharp AC, Laha M, Panizzi P, Thompson MW, FuentesPrior P, Bock PE. Plasminogen substrate recognition by the streptokinase-plasminogen catalytic complex is facilitated by Arg253, Lys256, and Lys257 in the streptokinase beta-domain and kringle 5 of the substrate. Journal of biological chemistry 2009; 284: 1951119521.

32. Chaudhary A, Vasudha S, Rajagopal K, Komath SS, Garg N, Yadav M, Mande SC, Sahni G. Function of the central domain of streptokinase in substrate plasminogen docking and processing revealed by sitedirected mutagenesis. Protein science 1999; 8(12): 2791-2805.

33. Zhang Y, Liang Z, Hsueh HT, Ploplis VA, Castellino FJ. Characterization of streptokinases from group A streptococci reveals a strong functional relationship that supports the coinheritance of plasminogen-binding $\mathrm{M}$ protein and cluster $2 \mathrm{~b}$ streptokinase. The journal of biological chemistry 2012; 287(50): 42093-42103.

34. Reed GL, Houng AK, Liu L, Parhami-Seren B, Matsueda LH, Wang S, Hedstrom L. A catalytic switch and the conversion of streptokinase to a fibrin-targeted plasminogen activator. Proceedings of the national academy of sciences 1999; 96(16): 8879-8883. 